\title{
INTERROGATOR INDEPENDENCE AND CHALLENGES OF HIS LACK OF INDEPENDENCE IN THE JUDICIAL SYSTEM OF IRAN AND FRANCE
}

\author{
M. Gholami
}

Faculty member of Department of Law, Payame Noor University, Iran

Published online: 15 February 2017

\begin{abstract}
The presence of legal procedure in courts does not always guarantee its fairness and factors such as the affiliation of the investigation authority with some organizations and institutions, closed investigation and prolongation of procedure may compromise the achievement of a fair outcome. The interrogator in criminal procedures is charged with important and momentous judicial tasks and for this reason, he should enjoy higher job security as in French law, an interrogator is not considered among the officials of public prosecutor's office and enjoys higher security. Code of Criminal Procedure of 2013 has established a positive view in connection with the interrogator's powers but on the other hand still puts great emphasis on some of the orientations whose trial and error have been performed in developed countries like France. Among these cases are the challenges such as the lack of full independence of the interrogator, violating the principle of impartiality, failure to determine appropriate sanctions to violate some of the principles of a fair trial and so on which have created problems in criminal procedures and need expertise in this regard. In this paper which has been conducted based on a descriptive-analytical method, the existing challenges in relation to the interrogator independence and challenges of his lack of independence are investigated due to the necessity of examining the duties and powers of the interrogator.
\end{abstract}

Keywords: Criminal procedure, fair trial, interrogator independence, Iranian law, French law

\footnotetext{
Author Correspondence, e-mail: author@gmail.com

doi: http://dx.doi.org/10.4314/jfas.v9i1s.690
} 


\section{INTRODUCTION}

An interrogator is a magistrate whose job is to interrogate the accused about the charge and investigate the charge by asking questions from the informants. Generally, detecting the crime and preventing the accused from escaping is among his most important duties [1]. In other words, an investigator or investigating judge or interrogator is an official who is responsible for carrying out the preliminary investigation of crimes and collection of reasons for and against the accused and performs his legal obligations under the supervision of prosecutors [2].

An interrogator is entrusted with crucial and important judicial functions and for this reason, he should enjoy greater job security as in many countries of the world, the interrogator is regarded as a sitting judge and enjoys higher security. For example, in France, the interrogator is not considered among the officials of the public prosecutor's office . In this country, the interrogator is selected for a period of 3 years from among the heads of misdemeanor courts with the presidential decree after observing legal formalities and necessary recommendations; and after the end of his mission, he can return to his former job or remain in his position for other periods [3].

Unlike the deputy and assistant prosecutor, the interrogator, as the case may be, is not obliged to follow the prosecutor in several and various cases in his appointments and decisions. Although the prosecutor monitors the interrogator in referring and issuing the order of investigations and supervision and necessary training to the interrogator, the law has made the interrogator independent and powerful in multiple cases with legal authority [4].

Concerning the impartiality of the judge especially the interrogator, with regard to accepting the principle of separation of prosecution from investigation, it should be said that investigation authority (interrogator) should be independent of prosecution authority (prosecutor) and should never be dependent on the prosecutor or the court or one of the parties and should maintain its own impartiality in all its actions. The main indicator that specifies the judge's justice in each position particularly in investigation and authority is the observance of impartiality. The interrogator should attempt to obtain the reasons for and against the accused and consider what he achieves in innocence or guilt of the accused. This condition has been always mentioned and emphasized in Rules of Procedure despite its obviousness [5].

Considering the importance of preliminary investigation which is the foundation of criminal proceedings, it is necessary for the investigation authority to be independent of the prosecutor, 
court, litigants and government. Unfortunately, in the law known as court revival approved in 2002, the interrogator who is the investigation authority was not fully independent of the prosecutor and in fact, it can be said that the law known as court revival practically puts the job of investigation and prosecution in the hands of one person who was the prosecutor and could sometimes intervene in the course of investigations and administration of judicial justice by applying his view [6].

\section{First discussion: Independence of the prosecutor}

In French law, the interrogator was previously considered as the judicial police officer. Hence, according to Article 57 and 249 of Criminal Investigations Act of 1808, he was under the supervision of the prosecutor. Referral of cases to interrogators was the prosecutor's responsibility while with regard to new ideas to protect the individual rights and freedoms and observe the equality of weapons, the prosecutor as one of the litigants should not have such a right (that is, no one has the right to choose his own judge). To avoid this and prevent the exertion of influence by the prosecutor over the interrogator in a variety of ways including taking the case assigned to him, reforms were carried out in French Code of Criminal Procedure [7].

One of the criticisms raised against the law of holding Public and Revolutionary Courts is the violation of this principle on the part of the aforesaid law because according to Rules of Procedure, investigation authority, prosecution authority and magistrate should be different since prosecution authority is the representative of a society against which the offender has done an action and is considered as one of the parties to a suit. Therefore, he should find reason against the accused whereas investigation authority has another duty. But in Article 93 of the Code of Criminal Procedure approved in 2013, this issue has been predicted and the following has been mentioned: "The interrogator should conduct the investigations with impartiality and within his jurisdiction and does not discriminate in discovering the circumstances and conditions that are against or in favor of the accused". However, as the sanction of observing impartiality, it has been mentioned in Note of Article 45 of the Code of Criminal Procedure approved in 1911 that its violation deserves disciplinary conviction from grade 3 above. But in the new law, this sanction has not been predicted.

\section{First chapter: Prosecutor's monitoring of preliminary investigations}

According to the new reforms of French Code of Criminal Procedure, the title of police officer was taken away from the interrogator and this led to withdrawal from the prosecutor's 
supervision. But another authority was determined to monitor the interrogator's job and a sitting judge who is the head of Provincial Court Charges Branch assumed this responsibility. According to Article 220 of French Code of Criminal Procedure, "the head of Charge Branch ensures the good function of interrogation branches of provincial court and tries that formalities have no unjustified delay". According to Article 83 of French Code of Criminal Procedure, division of works between interrogators has been taken away from the prosecutor and has been entrusted to President of the Court and in case of the existence of an obstacle, to his successor judge [8].

With regard to the principle of independence of judicial authorities, the prosecutor is the prosecution authority and the interrogator is the investigation authority and in principle, the prosecutor should not interfere in the interrogator's actions and decisions, but since the prosecutor is one of the public litigants, he has the right to protest like other litigants if actions and decisions of the interrogator are recognized to be illegal. However, he must be impartial and fully independent of the prosecutor [9].

Besides, the interrogator has no right to start prosecution and enjoys this right merely in certain cases. The interrogator has the right to start prosecution and investigation in special cases in which the prosecutor is not present and the evident crime happens in his presence. But this authority is temporary until the prosecutor becomes present. So, as soon as the prosecutor became present and the ground was provided for him to take action, the performed investigations should be made available to him so that he can refer them to another judge or the same interrogator [10]. Article 89 of the Code of Criminal Procedure states that the initiation of preliminary investigations on the part of the interrogator is dependent on the prosecutor's referral. If the interrogator witnesses the incidence of a crime, he begins to investigate and immediately informs the prosecutor of the facts and continues the investigations in case of the prosecutor's referral.

When the prosecutor entrusts preliminary investigations of the public trial to the interrogator, the interrogator should engage in investigations with full independence and without fear of obtrusiveness and interference of others. Thus, after referring the case to Interrogation Branch, the prosecutor is not entitled to take it back and refers it to another branch [11]. Article 339 of the new Code of Criminal Procedure states in this regard that after referring the case, it cannot be taken back and be referred to another branch except by the prescription of law. Note 1: 
Observance of the provisions of this Article about interrogation branches, Court of Appeal of the province and branches of the Supreme Court is necessary. According to Note 2 of Article 339, violation of the provisions of this Article leads to disciplinary conviction up to grade 4.

According to Article 73 of the Code of Criminal Procedure of 2013, in the affairs referred to the interrogator, the prosecutor has the right to monitor and provide necessary training. Also, Article 74 of the same law stipulates that the prosecutor can attend preliminary investigations and monitor the manner of their implementation but cannot stop the course of the investigation. Article 75 also specifies that monitoring the investigations is the responsibility of the prosecutor and investigations are performed in his domain although they are about an issue that has happened outside that domain.

Article 76 of new Code of Criminal Procedure acts based on the former procedure and states that the prosecutor can demand the interrogator to implement some necessary actions and investigations before he asks the interrogator to do investigations about a crime or entrusts the whole investigation to the interrogator. In this case, the interrogator is obliged to do only the investigation or action requested by the prosecutor and to send him the result. According to Article 105, the interrogator in the course of investigations implements the prosecutor's legal demand and mentions the facts in parliament document and whenever he is faced with difficulty in enforcement so that performing the demand is not possible, he announces the matter to the prosecutor. In line with making the investigation adversarial, the prosecutor's demand for conducting investigations by the interrogator is the prosecutor's right, but the interrogator should not have duty to do investigations. Accordingly, in some countries, if the prosecutor demands something from the interrogator, the interrogator can accept or reject it. But in case of rejection, he should issue a documented decree. On the other hand, the principle of the equality of weapons requires that if in line with making the investigation adversarial, the plaintiff, defendant or his lawyer demand for conducting an investigation in their favor, their demand is responded positively with the observance of some conditions and the interrogator comments and issues a documented decree about its acceptance or rejection, which in our law, such a provision has not been considered [12].

\section{Second chapter: Prosecutor's monitoring of criminal security order}

In performing preliminary investigations, if the evidence indicates the justification of the charge, the interrogator takes action to issue a criminal security order. The severity of accusation and 
reasons and documentaries of the case are sometimes such that they lead to the issuance of arrest warrant of the accused. In such cases, the interrogator independence necessitates that he acts based on his judicial opinion in issuing the security order and does not follow the vote or opinion of another judicial authority in public prosecutor's office especially the prosecutor. It is clear that in the event of issuing an inappropriate decree, the responsibility resulting from this action is entrusted to him [13].

After summoning the accused and explaining the charge to him, the interrogator should issue one of the security orders for the accused in case of the existence of enough evidence according to Article 217 in order to ensure the presence of the accused in other stages of investigation and trial. If in the old law, security orders were limited to five certain decrees including obligation with word of honor, obligation with penal clause, obligation with guarantee, obligation with bail and temporary detention in new Code of Criminal Procedure, a development took place in security orders and accordingly, security orders were divided into 10 groups ranging from obligation for presence with word of honor to temporary detention.

In the new law, the issuance of lightweight security orders such as obligation for presence with word of honor or penal clause or security actions such as non-exit from jurisdiction or intermittent recommendation to specific authorities or not leaving the house has been emphasized and in case of seriousness of charge reasons or fear of the defendant's escape, the interrogator can use the order of guarantee or bail or detention. Moreover, to observe the defendants' rights, if the interrogator wants to go on leave or duty, he should first make decisions about the cases whose defendants are under arrest and if there's the possibility of the defendant's freedom, he should take action in this respect.

Currently, numerous criticisms are raised against the competency of public prosecutor's office (including the interrogator, prosecutor and assistant prosecutor) to issue an arrest warrant. Human Rights Committee of International Civil and Political Covenant in various comments has considered the authority of public prosecutor's office for the detention of the accused as contrary to Paragraph 3 of Article 9 of International Civil and Political Covenant and has not specifically regarded the prosecutor as having the competent judicial authority mentioned in Paragraph 3 of Article 9 of the International Covenant since he cannot be considered as the independent and impartial authority [14]. 
In the Code of Criminal Procedure, the interrogator has full independence in issuing other criminal security orders in cases other than the issuance of temporary detention. According to Article 217, to access the defendant and his timely presence and prevent his escape or hiding and ensure the rights of the victim to compensate for his loss, the interrogator can issue one of the following security orders in case of the existence of enough evidence after explaining the charge and conducting necessary investigations.

In Article 240, a judgment has been determined for the issuance of temporary detention order. This article specifies that detention order of the accused should be immediately sent to the prosecutor. The prosecutor is obliged to declare his opinion to the interrogator in a written form within twenty-four hours. Whenever the prosecutor does not agree with the accused's detention order, dispute resolution is the responsibility of the competent court and the defendant is arrested until the issuance of the court's decision in this regard which does not exceed a maximum of ten days.

Apart from the fact that the interrogator independence has been violated against the prosecutor and the prosecutor practically interferes in the interrogator's investigations, entrusting this issue that this order should be approved by the prosecutor challenges and violates the principle of impartiality.

In order to achieve a just and fair trial, in the provisions of French Code of Criminal Procedure, the right to arrest the defendant has been taken away even from the interrogator who is responsible for investigation and collection of evidence since he is a member of public prosecutor's office. According to Article 145 of French Code of Criminal Procedure, in cases where the interrogator intends to detain the defendant, he should present his evidence to the impartial judge who has been called "judge of liberties and detention" in French law. Judge of liberties and detention is a sitting judicial officer and peer of the president, First Deputy or deputy president and is selected by the president of the town court [15].

\section{Third chapter: Prosecution desertion order}

Prosecution desertion order is a relatively new establishment which did not exist before the Code of Criminal Procedure of 1999. The basis for the formation of this legal establishment can be considered on one hand to be the influence of the achievements of "victimological" science on the legislator which in the process of investigation and judicial orientations and also in filing, prosecution and generally fate of the criminal case, more value is given to the demands of the 
private plaintiff. On the other hand, its basis is taken from a broader movement entitled restorative justice. Hence, it can be said that in law, this order has been considered in line with the victim-oriented policy. By issuing this order, the case does not become subject to adjudicated case validity; thus, the possibility of filing a second lawsuit does not exist with the conditions specified by the law. Further, the mentioned order is not among the objectionable orders.

In the new Code of Criminal Procedure approved in 2013, the legislator includes the prosecution desertion order in the law with some conditions and this time, the legislator removes the fault of the former law in this respect. The criticism made against the Article 177 of the former law was that the plaintiff can ask for a second hearing at any time and as many times as he wants after requesting for prosecution desertion and issuing this order and again launch the massive judicial system which has been stopped in relation to that case. Thus, in Article 79 of the new Code of Criminal Procedure, the legislator states that "in forgivable crimes, the plaintiff can ask for prosecution desertion before issuing the bill of indictment. In this case, the prosecutor issues the prosecution desertion order. The plaintiff can request for a second prosecution of the defendant only once and up to one year from the date of issuing the prosecution desertion order". As can be observed in this article, some limitations have been specified for the private plaintiff in using this right, including that first, he can raise such a request only for once and only in the stage of public prosecutor's office not the court and only before issuing the bill of indictment and second, he has an opportunity of one year for a second demand for prosecution of the defendant and after the passage of this time, he will not have such a right.

This entity is similar to the legal notification in French law. In legal notification to the defendant, legal obligations and duties are communicated and expressed. On the other hand, it is explained that in the event of subsequent violations of the law, he will be immediately prosecuted [16].

Following this action, town prosecutor uses filing the case if appropriate. For example, consider the case in which the police find a child and it becomes evident that he has been abandoned due to not being taken care of by the parents. In this case, the police remind them that this action is a crime and deserves punishment. But the parents of this child make a written commitment that they will make considerable effort in education and care of their child. A text addressed to the prosecutor from the police suggests that filing the case is requested [17].

\section{Fourth chapter: Conducting preliminary investigations by the prosecutor}


Prosecutor as the representative of the public prosecutor is obliged to prosecute in case he is aware of the occurrence of a crime in order to protect individual and public rights. But after starting the prosecution of the defendant and his detention or summons, the duty of investigations concerning the occurrence or non-occurrence of the crime is assumed by the interrogator as the investigation authority. Indeed, the interrogator as an impartial authority investigates between the arguments of the crime announced by the prosecutor and defenses asserted by the defendant to rescue himself and then, he gives his opinion about the defendant being guilty or not.

The necessity of separation of prosecution and investigation authorities was established in public prosecutor's office in France. According to Article 47 and in subsequent amendments and in set of rules in the Code of Criminal Procedure of Article 31 onwards and also Article 49 onwards, the legislator of 1808 in France separates the duty of pursuing the lawsuit from preliminary investigations and entrusts the former to the prosecutor and the latter to the interrogator. The situation of this judgment is different. The interrogator is a court judge and is unchangeable for this reason. But the town prosecutor is a judge of public prosecutor's office and can be changed and deposed and is dependent on the Minister of Justice. These two people are different from each other particularly in terms of duties. Public prosecutor's office which has only the right of prosecution is not entitled to carry out preliminary investigations [18]. In Article 49 of French Code of Criminal Procedure, the interrogator is responsible for conducting preliminary investigations and this article refers to the separation of investigation authority from prosecution authority by stating the title of "interrogator and first grade investigation authority" at the top of the first chapter in the third section of French Code of Criminal Procedure and the interrogator as the independent authority investigates about the crimes and the prosecutor is not entitled to investigate about any crime.

Generally, in French law, three judicial authorities intervene in the course of a criminal case, who include the following: 1) Public prosecutor's office which runs the trial; 2) judicial authorities of investigation who collect the evidence and 3) courts that issue the final verdict [19].

According to the provisions of French Code of Criminal Procedure, the prosecution authority principally does not have the right to conduct preliminary investigations and the prosecutor whose duty is to evaluate the legality and expediency of prosecution may need extra information 
for decision-making and Article 75 onwards in French Code of Criminal Procedure gives permission to the judicial police to do it.

In France, regarding the evident crime, the prosecutor is allowed to do some actions which can also be performed by judicial police officers before arriving the prosecutor in order to prevent the elimination of the causes of the crime and facilitate the justice work. But these authorities are not the real preliminary investigations. Paragraph 2 of Article 68 of French Code of Criminal Procedure simply considers these actions as the job of the judicial police [20].

But according to Article 92 of the Code of Criminal Procedure of 2013, "preliminary investigations for all crimes are the responsibility of the interrogator. In connection with crimes other than those deserving the punishments specified in Article 302 of this law, in case of shortage of interrogators, the prosecutor also has the duties and powers determined for the interrogator. In this state, if the prosecutor refers preliminary investigations to the assistant prosecutor, final orders of the assistant prosecutor and also security order leading to the arrest of the accused should be announced to the prosecutor on the same day of issuance and the prosecutor is obliged to offer his opinion within a maximum period of twenty-four hours". Then, with regard to the ability of the judicial system, the law has permitted the prosecutor to take on the interrogator's duties in some of the crimes in the absence of the interrogator. However, in important crimes mentioned in Article 302, the prosecutor does not have the right to investigate and in this case, the necessary investigation will be performed by the court magistrate when the interrogator is not present.

If the interrogator is not present in a place or is excused from hearing for legal reasons (e.g., blood relationship and kinship by marriage between the defendant and interrogator), in cases other than the important crimes contained in Article 302, the prosecutor instead of the interrogator is entitled to investigate about the crime which in this case, he can refer the investigation to one of the assistant prosecutors in public prosecutor's office; but since the assistant prosecutor does not have independence in decision-making, he should perform his duties under the supervision of the prosecutor and if the assistant prosecutor wants to issue the arrest warrant of the defendant, he should get the agreement of the prosecutor in this regard. As it stands, the independence of investigation authority from prosecution authority has been explicitly violated and this principle of impartiality is challenged in preliminary investigations.

\section{Second discussion: Independence from the court}


The philosophy of the interrogator independence from the court is that the interrogator is charged with investigations and if he has issued the arrest warrant of the defendant to the trial, he is certainly committed to his opinion by sitting in the authority of issuing the verdict and considers the defendant to be guilty and votes against him which this issue is contrary to the defense rights of the accused and fair and equitable criminal procedure [21].

Since the interrogator is one of the authorities of the public prosecutor's office, and public prosecutor's office also performs its duties in company with the court, the interrogator has no independence of the court and has to follow the court's decision in cases of dispute between the interrogator and prosecutor, which articles 240, 241, 269, 271 and 272 also imply this issue [22]. According to Article 362 of the Code of Criminal Procedure, the court performs any investigation or action that is necessary to find the truth with the stipulation of its necessity in addition to addressing the arguments contained in the bill of indictment or the evidence cited by the parties. In this case, the independence of the interrogator as the prosecution authority is compromised and the court challenges this issue. Another example is Paragraph A of Article 389 which states that if the criminal court recognizes the investigations to be incomplete, it issues an order for the elimination of defects and sends the case to the public prosecutor's office that has issued the bill of indictment so that it restitutes without giving opinion after doing the court order.

Other cases are Article 276 and Article 277 of the new law. Article 276 stipulates that in case of violating the order of prohibiting the prosecution and issuing the arrest warrant to the trial by the court, the interrogator is obliged to summon the defendant and explain the subject of the charge to him and send the case to the court by adopting the latest defense and proper security of him. Article 277 has specified that in case of violating the cessation of prosecution order, the interrogator deals with the case according to the regulations and regardless of the direction that is the cause of violating the cessation of prosecution order and makes an appropriate decision by conducting the necessary investigations.

\section{Thirds discussion: Independence from the litigants}

The interrogator is independent of the litigants and is a judicial authority and decision-making is done by him and the parties can never impose the issuance of a decision or demand on him. He can make any decision that is necessary to discover the truth and the litigants have the right to protest the made decisions before the law and he issues any criminal security order which he 
deems as necessary and the determination of the parties has no effect on the issuance of such orders or other numerical orders and final orders [23].

\section{Conclusion}

In summary, it can be said that hearing is fair if it deals with preserving the balance between interests of the society and the accused and the defendant is tried under absolutely free conditions while enjoying all necessary guarantees for defense. In fact, the right of a fair trial is one of the fundamental elements of the rule of law. The interrogator is entrusted with important and momentous judicial functions and for this reason, he should enjoy greater job security as in France, the interrogator is not considered among the officials of the public prosecutor's office. Unlike the deputy and assistant prosecutor, the interrogator is not obliged to follow the prosecutor. Although the prosecutor monitors his job, the law has made the interrogator powerful and independent in multiple cases with legal authorities.

As to the challenges of the interrogator's orders, in Iranian Code of Criminal Procedure, a procedure is still followed that has been abolished for years in developed countries. According to the regulations of French Code of Criminal Procedure, prosecution authority is not principally entitled to conduct preliminary investigations and the prosecutor who has the duty of evaluating the legality and expediency of prosecution may need extra information for decision-making and Article 75 onwards of French Code of Criminal Procedure permits the judicial police to do this issue. There are some principles based on scientific findings that have not been properly taken into account in Iranian law especially Code of Criminal Procedure of 2013. Besides, some powers have been given to the interrogator which it was better not to so that the fair trial is not faced with challenges. For example, in French law, with regard to the reforms which have taken place in the 1990s, not only the extension of the arrest warrant but also its issuance which occur at the request of the interrogator are among the powers of the judge of liberties and detention. The aforesaid judge makes a decision after hearing the defense of the defending attorney of the accused against the judge's demand for detention. In Iranian law, it was appropriate to design the system so that at the end of the preliminary investigations conducted by the interrogator, an impartial judge can announce his own decision about the necessity or non-necessity of temporary detention in a meeting in an adversarial manner. Generally, in the Code of Criminal Procedure, there are good points about the observance of a fair trial and great efforts have been made to protect the rights and freedoms of citizens. But on the other hand, some of the orientations whose 
trial and error have been performed in developed countries have been strongly emphasized and trial and error should continue which is one of the challenges of the interrogator independence and also duties and powers assigned to him which are not reviewed in some cases.

Accordingly, the following recommendations can be presented: 1) Full independence of the interrogator must be provided in doing the duties and powers; 2) regarding the issuance of temporary detention order, it is appropriate that an impartial body such as the judge of liberties and detention be predicted in Iranian law; 3) appropriate sanctions for violating the principles of a fair trial should be predicted in law which have not been predicted in some ways; 4) instances of arrest without summons are appropriate to be moderated in Iranian law and a suitable measure should be specified in this regard for determining the instances which include other important crimes.

\section{REFERENCES}

[1] Ja'fari Langroodi, Mohammad Ja'far, Terminology of Law, Fifteenth Edition, Ganje Danesh, Tehran, 2005, p. 88.

[2] Akhoundi, Mahmoud, Criminal Procedure, Publication of the Ministry of Culture and Islamic Guidance, Volume II, Tehran, 2005., p. 54

[3] Akhoundi, ibid., Vol. 2, p. 54.

[4] Ya'qoubi, Abdol Hashem, How to handle crimes in the court of Justice, Sixth Edition, Ferdowsi Publishing, Tehran, 2003, p. 33.

[5] Shamlou, Mohammad Hosein, Public prosecutor's office and preliminary investigations, First Edition, Dadyar Publishing, Isfahan, 2004, pp. 47-48.

[6] Ibid., P. 65

[7]Ibid., P. 65

[8] Shamlou, Mohammad Hosein, Public prosecutor's office and preliminary investigations, First Edition, Dadyar Publishing, Isfahan, 2004. P. 65-66.

[9] Ashouri, Mohammad, The position of public prosecutor's office and the defense rights of the accused in the new criminal policy, Tehran Public Prosecution Office, Series of lectures of the first meeting of capital prosecutors of Islamic countries, Tehran, Tehran Public and Revolution Court, 2007, p. 80. 
[10] Zera'at, Abbas, Code of Criminal Procedure, First Edition, Vol. 2, Mizan Publishing, Tehran, 2014, p. 44.

[11] Ibid., Vol. 2, p. 44

[12] Ibid., Vol. 2, p. 81.

[13] Fathi, Mohammad, Dehqani, Ali, Interrogator independence in conducting preliminary investigations and its impact on the realization of a fair trial, Law and Jurisprudence, 5 (20), Spring 2009, p. 99.

[14] Ashouri, Mohammad, Bahmani Qajar, Mohammad Ali, Procedure of the Human Rights Committee in support of the right for liberty and personal security. Quarterly journal of Law, Faculty of Law and Political Science, New period, No. 3, Tehran, Fall of 2008, P. 12-13.

[15] Tadayyon, Abbas. French Code of Criminal Procedure, First Edition, Official newspaper of the Islamic Republic of Iran, Tehran, 2009, p. 126

[16] Guinchard (S), Buisson (J), "procédure pénale"; Litec.- J. Leblois- Happe; (1994) "La médiation pénale comme mode de réponse à La petite délinquance: état des lieux et perspectives" Rev.sc.crim, 2005, p. 651. Cited in Khoushki, Gholamhasan, Alternatives of public lawsuit prosecution in criminal justice system of Iran and France, Journal of Public Law Research, No. 29, Summer 2010, P. 334.

[17] Desdevises Marie-clet;(2006) "L’option entre prévention et répression: Les alternatives aux poursuites, un nouveau droit pénal des majeurs" in: Le champ pénal; Mélanges en l'honneur du professeur Reynald ottenhof; Dalloz, 2006, p. 174. Cited in Khoushki, Gholamhasan, the former, P. 334.

[18] Stephanie, Gaston et al. Code of Criminal Procedure, Volume 1, First Edition, Translated by Hasan Dadban, Allameh Tabatabaei University Press, Tehran, 1998, pp. 46-47.

[19] Largiyeh, Jean, Code of Criminal Procedure, Translated by Hasan Kashefi Esmaeilzadeh, First Edition, Ganje Danesh Publications, Tehran, 1999, P. 35.

[20] Stephanie, Gaston et al. Code of Criminal Procedure, Volume 1, First Edition, Translated by Hasan Dadban, Allameh Tabatabaei University Press, Tehran, 1998, pp. 47.

[21] Abouzari, Seyyed Ali, Interrogator and interrogation in the Iranian criminal legal system, First Edition, Negah Bineh, Tehran, 2015, p. 52.

[22] Ibid., p. 51.

[23] Ibid., P. 54 
How to cite this article:

Gholami M. Interrogator independence and challenges of his lack of independence in the judicial system of iran and france. J. Fundam. Appl. Sci., 2016, 9(1S), 261-275. 